\title{
The Nexus between Digital Finance and Economic Development: Evidence from China
}

\author{
Xiuxiu Jiang $\mathbb{D}^{\mathbb{1}}$, Xia Wang, Jia Ren * and Zhimin Xie \\ School of Economics and Management, Tongi University, Shanghai 200092, China; 1910480@tongji.edu.cn (X.J.); \\ tjxiawang@sina.com (X.W.); xie_6@126.com (Z.X.) \\ * Correspondence: 1830376@tongji.edu.cn; Tel.: +81-191-4569-8645
}

\begin{abstract}
In the context of the digital economy and based on the characteristics of digital financial development in China, this paper investigates the effect of digital finance on economic growth and explores its influencing mechanism. A panel econometric model, mediating effect model, and instrumental variable method were employed to evaluate yearly data from 30 provinces of China from 2011 to 2018. The results show that the development of digital finance has significantly driven economic growth, which is quantitatively robust after the selection of historical data as instrumental variables and other robustness tests. A heterogeneity analysis proved that provinces in the central and western regions, which have a lower urbanization rate and lower physical capital, more clearly embody the facilitating impacts of digital finance on economic growth compared to their counterparts in other regions. Further analysis found that the development of digital finance has spurred the liberation of regional entrepreneurship, which in turn promoted economic growth-that is, there is an entrepreneurial channel by which digital finance could boost economic growth.
\end{abstract}

Keywords: digital finance; economic growth; entrepreneurship; China

Citation: Jiang, X.; Wang, X.; Ren, J.; Xie, Z. The Nexus between Digital Finance and Economic Development: Evidence from China. Sustainability 2021, 13, 7289. https://doi.org/ $10.3390 /$ su13137289

Academic Editors: Donato Morea and Marc A. Rosen

Received: 14 May 2021

Accepted: 25 June 2021

Published: 29 June 2021

Publisher's Note: MDPI stays neutral with regard to jurisdictional claims in published maps and institutional affiliations.

\section{Introduction}

Since the reform and opening-up, China's GDP has grown by an average of $9.4 \%$ per year, with the country quickly becoming the world's second-largest economy-a phenomenon known as the "Chinese miracle" [1]. By 2020, China's surveyed unemployment rate was below $5.3 \%$, the per capita disposable income of residents exceeded 4348 USD, and China had lifted 11.09 million rural people out of poverty over the previous year and turned into a middle- to upper-income country [2]. Confronted with a series of internal and external factors, including the risk of the "middle-income trap," the in-depth adjustment of the international economic structure, and so forth, China's economic growth has slowed down, and economic development is now in the situation of the "new normal" [3]. How to shift the economic growth pattern from over-reliance on investment to that driven by entrepreneurship and innovation is a major issue in the sustainable development of China. Meanwhile, the digital economy is the most active field in China's economic development, and one of its major features is that it is based on a new financial system supported by information technology, so it continues to expand into various economic and social fields, playing an important role in stimulating consumption, encouraging investment, and job creation. Cultivating new kinetic energy with informatization, driving the mode of production through digital transformation, and unleashing the power of the digital economy to build a "Digital China" are important elements in China's quest to achieve sustainable and sound development.

Economic development cannot be separated from the support of finance, which is an inextricable part of the process of growth [4]. In recent years, with the in-depth integration of information technology and finance, digital finance-a new financial model-has gradually become an indispensable dimension of China's financial system; it is conducive to the advancement of conventional financial sectors and institutions, realizing the transformation 
of financial business from being credit- and collateral-based to being data-based [5]. For example, the Internet of Things generates a wealth of data; artificial intelligence and cloud computing improve the efficiency of data processing; big data provide timely feedbacks and are promising for reshaping and re-engineering business models [6], and blockchain facilitates the updating and real-time dissemination of data. Besides, digital applications are cheaper and may allow for timely cost reduction [7]. Existing studies have argued that digital finance, involving digital financial services and products such as online credit, mobile payment, digital crowdfunding, e-commerce supply chain finance, etc., has a multidimensional and compound impact on economic performance. On the one hand, the emergence and popularization of the Internet and other innovative technologies can form an economic environment covering economies of scale, economies of scope, and the long tail effect, which is conducive to realizing the transformation of traditional models of credit business, matching supply and demand across geographical boundaries and thus introducing a better pricing system to achieve economic equilibrium [8]. On the other hand, a closer association between the Internet and the financial industry has created a new development ecology $[9,10]$, broadening the financing channels for small and medium-sized enterprises and vulnerable groups, lowering the threshold of financial services, improving the convenience of funding, and thus causing economic activities to prosper. According to the Digital Financial Inclusion Index released by Peking University [11], from 2011 to 2018, the average value of the index increased from 40.00 to 300.21 , indicating that digital-inclusive finance is booming in China. However, to what extent does digital finance affect economic growth and through what path? Is the effect of digital finance on economic growth heterogeneous, owing to differences in geographic location and factor endowments? This paper endeavors to answer these questions. Originating from Schumpeter's innovation and endogenous growth theory [12,13], entrepreneurship, the mechanism of "creative destruction", formed based on innovation activities, plays an enabling role in pushing forward technological progress, promoting economic structural adjustment and endogenous economic growth. Therefore, this paper attempts to explore the influencing mechanism of digital finance on economic growth from the perspective of entrepreneurship. The research in this paper not only helps us to thoroughly understand the impact of digital finance on China's economic growth but also provides experience and a reference for developing countries and emerging economies.

Specifically, based on the digital inclusive finance index released by Peking University and China's provincial panel data from 2011 to 2018, combined with the characteristics and unique attributes of digital finance, this paper examines the nexus between digital finance and economic growth as well as its heterogeneous impact, and further explores its influencing mechanism. Moreover, the historical data on the number of fixed-line telephones and per capita post and telecommunications businesses in each province in 1984 were selected as instrumental variables to palliate the effects of endogeneity, and other robustness checks were also carried out. It turns out that digital finance has significantly promoted economic growth, especially in China's central and western regions and areas with a lower urbanization rate and lower physical capital, in comparison with their counterparts in other areas. Further research shows that entrepreneurship is an intermediary variable that enhances the positive impact of digital finance on economic growth.

The contribution of this paper lies in the following aspects. Firstly, drawing on the existing literature, in the context of China's vigorous development of digital economy, this paper examines the nexus between digital finance and economic growth at a macro level and reports the nuanced heterogeneous influence in terms of geographic location and the level of urbanization development and physical capital. This not only deepens our understanding of the construction of a "Digital China," but also enriches the literature on digital finance. Secondly, in considering the fundamental issue of how digital finance influences economic development, a mediation effect model is adopted to further evaluate the strengthening effect of entrepreneurship on the path by which digital finance affects economic growth; this deepens the existing literature. Thirdly, taking into account the en- 
trepreneurial spirit of innovation, pioneer spirit, and risk-taking, we establish a composite index to proxy entrepreneurship, which could embody the connotation and characteristics of entrepreneurship more accurately and comprehensively than previous studies. Additionally, this paper employs historical data as instrumental variables to control endogeneity, which increases the robustness of the main conclusions.

The remainder of the paper is arranged as follows. Section 2 is devoted to a literature review. Section 3 introduces models, gives a description of the data, and conducts a preliminary investigation. Section 4 presents and interprets the results. Section 5 concludes the paper and provides relevant policy implications.

\section{Literature Review}

There is a broad consensus that financial development conduces to economic growth for academics and practitioners $[14,15]$. The core function of finance is to optimize the allocation of resources while reducing risks as much as possible. Relevant empirical findings showed that financial development helps to manage risks, decrease external financing costs [14], encourage consumption [16,17], reduce liquidity constraints, and facilitate transactions [18]. The nexus between financial systems (in respect of financial deepening) and growth remains arguable. Schumpeter [19] underlined the fact that a banking system plays an essential role in economic growth. Levine [15] verified that the banking system, as a robust and solid financial intermediation system [20], could effectively alleviate the external financing constraints of enterprises, thereby leading to long-term economic growth and productivity improvement. In general, these arguments affirmed the relationship between financial investment and growth.

However, the development of China's financial system is still far from impeccable, which has seriously inhibited sustainable economic growth [21,22]. The phenomenon of financial repression is widespread in developing countries and emerging economies $[23,24]$, manifesting in restrictions on deposit and loan interest rates and supervision to capital accounts [25], and China is no exception. China's traditional financial system is dominated by banks, which carry out business on the basis of credits and collaterals. Rigorous risk control and management have led to difficulties in gaining access to financial services for small-, medium-, and micro-sized enterprises, which puts them at a disadvantage. Moreover, the banking sector in China is mainly dominated by state ownership [26]; thus, interest rates and credit allocation are heavily affected by political factors, leading to market failures. Furthermore, there are inefficiencies and distortions in the traditional financial system, embodied in many aspects such as inadequate competition of commercial banks, resulting in excessive profits and insufficient rural financial supply. Financing constraints, such as difficult and expensive financing, have restrained the sustainable and healthy development of China's economy, and also promote the vigorous development of digital finance as a new financial model in China [27].

In recent years, digital finance, relying on innovative technologies such as information technology, big data technology, and cloud computing, has provided a huge scope for development to reduce financial transaction costs, tap into the potential demand of users, and expand the scope and accessibility of financial services [28,29]. For traditional financial sectors such as banks, digital finance is promising to lower costs by reducing queues in banks, minimizing paperwork and documentation, and requiring fewer branches and physical outlets [30]. For the financial and monetary supervision departments, digital finance is instrumental to reducing the quantity of physical cash in circulation and helps to curb high inflation in developing and poverty-stricken countries [31]. With regard to enterprises and individuals, digital finance has enriched the channels of financing and credits, simplified transaction procedures, and promoted the availability and convenience of financial services [32,33]. As a new financial model, digital finance has become a powerful complement to the traditional financial system, affecting many aspects of economic performance.

The existing literature links digital finance and growth, directly or indirectly, to issues such as traditional financial market, financing, household consumption, gender equality, 
and poverty reduction. To this end, a review of digital finance and issues related to growth and economic performance is presented. In terms of the traditional financial market, the emergence and evolution of digital finance urges the transformation of incumbent providers of banking business and financial services, and thus diversified, cost-efficient, and intelligent financial products and services are required to reach new levels of usercentricity [5,34]. Research shows that information asymmetry, a lack of sufficient collateral, and higher borrowing costs are the main reasons why micro-, small-, and medium-sized enterprises (MSMEs) face greater financing constraints compared with big businesses. Incorporating asset-backed bonds into the blockchain to increase transparency, automating cumbersome processes, and opting for loans from innovative digital platforms such as digital crowdfunding and peer-to-peer platforms, can lower financing barriers and costs and improve the efficiency and accessibility of financial services for MSMEs [35,36]. As far as household economics and consumption go, Grossman and Tarazi pointed out that the prevalence of digital financial services makes it easier and more convenient for smallholder farming families to save, borrow, and manage income and assets. With the continuous expansion of the digital ecosystem, such as more mobile phones and greater network coverage, digital finance will bring about more convenience and support for peasant households [37]. Based on an empirical analysis in China, Li found that digital finance could boost household consumption by improving the convenience of borrowing, reducing liquidity constraints, and broadening the investment channels [38]. When it comes to gender equality, Kromidha [39] and Kusimba [40], in the context of India and Kenya, respectively, focused on the nexus of digital financial services and products, such as digital crowdfunding, smartphones, digital credit services, etc., and how they affect women's access to finance and gender equality in entrepreneurship. As to poverty alleviation, Ozili argued that digital finance plays a beneficial role in financial inclusion and stability [41], but when providing digital financial services to the poor, government intervention may be required to reduce the risks of the digital financial system, so as to achieve the dissemination of digital financial services for the poor [42].

On the grounds of the above arguments, it is clear that digital finance, as an indispensable part of the traditional financial market, has penetrated deep into almost all aspects of the economy. Its innovative advancements in terms of Internet financing and insurance, mobile payment, digital crowdfunding, and online credit can advance the infiltration of financial services, granting access to financial services to entrepreneurs, easing the financial pressure on enterprises, and thus prompting economic development. Notwithstanding, empirical studies that accurately assess the role of the digital economy in economic growth are scarce, especially in the context of China's digital economy. Therefore, this paper investigates the possible impact of digital finance on economic growth based on several dimensions of digital finance and explores its potential influencing mechanisms.

\section{Methodology and Data}

\subsection{Models}

This study is designed to investigate the impact of digital finance on economic development in China in consideration of key determinants. The paper firstly builds the following benchmark model to test the direct transmission mechanism:

$$
\ln P G D P_{i t}=\beta_{0}+\beta_{1} I N D E X_{i t}+\beta_{c} X_{i t}+\mu_{i}+\varepsilon_{i t},
$$

where $\ln P G D P_{i t}$ is the dependent variable measured by the logarithm of per capita GDP, which indicates the economic development of area $i$ in period $t$. Additionally, GDP is used as an alternative explained variable in the robustness examination. Both of them are deflated at constant 2000 prices to eliminate the influence of inflation. INDEX $X_{i t}$ is the core explanatory variable that denotes the level of digital finance development of area $i$ in period $t . X_{i t}$ represents a series of control variables. $\beta_{0}$ is a constant term; $\beta_{1}$ is the corresponding regression coefficient, representing the marginal effect of digital finance 
development on economic development. $\mu_{i}$ denotes the individual fixed effect. $\varepsilon_{i t}$ is the random disturbance term.

As mentioned above, digital finance can cultivate more entrepreneurial opportunities by influencing transaction costs, knowledge spillover, and financial service efficiency, and enriches entrepreneurial resources by accelerating information interaction and the diffusion of ideas to promote regional entrepreneurship. On the other hand, entrepreneurship, as the endogenous dynamism of economic growth, plays an important role in economic performance such as job creation, poverty reduction, industrial upgrading, and structural transformation $[43,44]$. To further clarify how digital finance influences economic growth, based on the classical mediating effect model, this paper examines whether entrepreneurship is the mediating variable that affects the relationship between digital finance and economic growth. The specific steps are as follows: Firstly, test the total effect of core explanatory variable $I N D E X_{i t}$ on the dependent variable $\ln P G D P_{i t}$ in Equation (1). If $\beta_{1}$ is significant, it indicates the possibility of a mediating effect. Then the stepwise regression method or bootstrap method is used to test the significance of coefficient $\varphi_{1}$ in Equation (2) and $\tau_{2}$ in Equation (3) to determine whether a mediating effect exists. The specific mediating effect model is set as follows:

$$
\begin{gathered}
\text { ENTREP }_{i t}=\varphi_{0}+\varphi_{1} \operatorname{INDEX}_{i t}+\varphi_{c} X_{i t}+\mu_{i}+\varepsilon_{i t} \\
\ln \operatorname{PGDP}_{i t}=\tau_{0}+\tau_{1} I_{N D E X_{i t}}+\tau_{2} \text { ENTREP }_{i t}+\tau_{c} X_{i t}+\mu_{i}+\varepsilon_{i t}
\end{gathered}
$$

where $i$ and $t$ represent the cross-section and time periods, respectively. ENTREP $P_{i t}$ refers to regional entrepreneurship.

\subsection{Description of the Data \\ 3.2.1. Core Explanatory Variable}

The digital finance index (DF) used in this paper was created by Peking University to reflect the development of digital inclusive finance [11]. The index was compiled by a joint research group including the Institute of Digital Finance of Peking University, the Institute of Finance of Shanghai University, and Ant Financial Services Group on the basis of big data on trading accounts on digital inclusive finance from Ant Financial Services, which is of great credibility and research value [38,45]. This index system covers three dimensions of digital financial services: coverage breadth (C_D), usage depth (U_S), and digitization level (D_L). Coverage breadth reflects the account coverage, usage depth reflects the real effect of the development of digital finance, and the digitization level is the embodiment of Internet technology. In addition, six categories are covered in the index, i.e., payment, insurance, monetary fund, investment, credit, and credit investigation. This paper mainly used the provincial data of aggregated index and three first-level indices for empirical analysis, and all indexes adopted were divided by 100 .

\subsubsection{Mediating Variable}

As a powerful supplement to the traditional financial system, digital finance provides important support to entrepreneurship. Firstly, digital finance, which relies on Internet technology, provides financial support for innovative and entrepreneurial activities by alleviating financial exclusion and expanding the accessibility of financial services [41], which helps to enhance its risk-taking nature. Secondly, the development of digital finance has nurtured distributed business structures, which are more inclusive and permeable, help entrepreneurs communicate and cooperate in the distributed innovation network, and lay the foundation for further innovations of entrepreneurs in the future. Meanwhile, digital finance realizes the open sharing of resources between different entities through the digitization of assets, effectively alleviating the information asymmetry of financial elements and misallocation of financial resources [46]. Digital finance makes it possible for consumers and merchants to complete transactions online, changes the form of value delivery in business models [8], releases substantial new business opportunities, and makes 
it possible for companies to discover and grasp market opportunities to achieve business expansion. In general, digital finance affects almost every aspect of entrepreneurship.

In existing research, entrepreneurship was mainly proxied by a single index such as the self-employment rate, new firm formation rate, small business ownership rate, and so forth [47-50]. Since entrepreneurship is an abstract and comprehensive concept, a single index cannot fully reflect its features and connotations. Combined with the previous studies, this paper establishes a composite evaluation index of three dimensions covering innovation, risk-taking, and pioneering, considering the characteristics of entrepreneurs' behavior and the internal factors and external environment of enterprises. Innovation is the essence of entrepreneurship, emphasizing the spirit of creative reorganization [51]. Entrepreneurs innovation mainly refers to the input of innovative elements, including innovative talents and capital, while innovation outputs reflect the effectiveness of innovation in a region. An innovation network is an important support for the technological innovation activities of enterprises, conducive to the industrialization of technological achievements, maintaining and promoting the formation of a social network, and giving new enterprises access to an innovation ecosystem [52]. In terms of pioneering, enterprises with this characteristic tend to have a more long-term vision, meaning that they can achieve higher economic performance than their competitors. The pioneering of entrepreneurs is generally manifested in some behaviors such as the establishment of brand recognition [53], technical contract transactions, and capital market operations [54,55]. This paper uses brand awareness, technology introduction, economic openness, development speed, and financial depth to measure the pioneering of entrepreneurship. As to risk-taking, entrepreneurs can choose some actions to demonstrate their risk tolerance and risk-taking such as starting a new business, hiring new employees, expanding the scale of enterprise production, or assuming higher financial leverage [56]. Therefore, market density, expansion tendency, and financial leverage are used to measure risk-taking in this paper.

Next, a principal component analysis (PCA) was performed to normalize and aggregate variables to form a composite index. The specific indicators are shown in Table 1.

Table 1. Entrepreneurship evaluation index system.

\begin{tabular}{|c|c|c|}
\hline $\begin{array}{l}\text { First-Level } \\
\text { Indicators }\end{array}$ & Second-Level Indicators & System Formation \\
\hline \multirow{7}{*}{ Innovation } & \multirow{5}{*}{ Innovation network } & Number of National Technology Business \\
\hline & & Incubators \\
\hline & & Torch Center Maker Space \\
\hline & & Income Scale of the Software Industry of the \\
\hline & & Torch Program \\
\hline & Innovation inputs & $\begin{array}{c}\text { Number of R\&D Personnel per 10,000 People } \\
\text { R\&D Investment Intensity }\end{array}$ \\
\hline & Innovation outputs & $\begin{array}{l}\text { Number of Patent Applications Accepted per } \\
10,000 \text { People }\end{array}$ \\
\hline \multirow{6}{*}{ Pioneering } & \multirow{2}{*}{ Brand awareness } & Number of Effective Trademark \\
\hline & & Registrations per 10,000 People \\
\hline & Technology introduction & Absorbed Technology Turnover \\
\hline & Economic openness & Percentage of Total Imports and Exports \\
\hline & Speed of development & Number of Unicorn Companies \\
\hline & Financial depth & $\begin{array}{l}\text { Proportion of Financial Institution Loan } \\
\text { Balance }\end{array}$ \\
\hline \multirow{3}{*}{ Risk-taking } & Market density & $\begin{array}{l}\text { Number of Market Entities Owned per } \\
10,000 \text { People }\end{array}$ \\
\hline & Expansion tendency & Average Value of Output Scale of Enterprise \\
\hline & Financial leverage & Debt to Asset Ratio \\
\hline
\end{tabular}

\subsubsection{Control Variables}

This study aims to examine the impact of digital finance on economic development in China, key control variables should be considered to control the influence of other 
factors on the dependent variable. Existing literature has listed substantial factors that affected economic development [57-59]; therefore, the following control variables were used: The Cobb-Douglas Production function is widely used in research on economic growth, and capital input and labor input are the two basic production factors. So, the logarithm of the total fixed assets of the whole society is used as the proxy variable of capital input $(\operatorname{lnCAP})$, and the logarithm of labor force at year end is used to measure labor input (lnLAB) in this paper. Moreover, government intervention (GI) represents the degree of regional government intervention, measured by the proportion of regional fiscal expenditure to GDP. Urbanization (URB), which can bring human and material capital to a region to boost economic growth, is proxied by the proportion of urban population to the total population at year end. Industrial structure (IS) reflects the economic structure in a region, measured by the proportion of the added value of the secondary industry to GDP. Physical infrastructure (lnINF) is a fundamental guarantee of the survival and prosperity of enterprises and a solid foundation for the sustainable development of a region, measured by the logarithm of urban road area per capita.

Considering the availability of data, this paper used the panel data from 30 provinces of China (excluding Tibet, Hong Kong, Macao, and Taiwan) during 2011-2018 for the empirical analysis. The data were mainly derived from the China Statistical Yearbook, China Science and Technology Statistical Yearbook, the Torch Center website of the Ministry of Science and Technology, and the Wind database. Linear interpolation was used to tackle the problem of outliers or missing values. The variable descriptions are given in Table 2.

Table 2. Descriptive statistics.

\begin{tabular}{|c|c|c|c|c|c|c|}
\hline & Variables & Symbols & Mean & Std. Dev. & Min & Max \\
\hline \multirow[t]{2}{*}{$\begin{array}{c}\text { Dependent } \\
\text { Variable }\end{array}$} & Economic Growth & $\operatorname{lnPGDP}$ & 10.3686 & 0.4694 & 9.2020 & 11.6281 \\
\hline & Digital Finance & $\mathrm{DF}$ & 1.8819 & 0.8498 & 0.1833 & 3.7773 \\
\hline \multirow{3}{*}{$\begin{array}{l}\text { Independent } \\
\text { Variables }\end{array}$} & Coverage Breadth & C_D & 1.6793 & 0.8272 & 0.0196 & 3.5387 \\
\hline & Usage Depth & U_S & 1.8353 & 0.8488 & 0.0676 & 4.0040 \\
\hline & Digitization Level & D_L & 2.6353 & 1.1665 & 0.0758 & 4.5366 \\
\hline \multirow{3}{*}{$\begin{array}{l}\text { Mediator } \\
\text { Variable }\end{array}$} & Entrepreneurship & ENTREP & 0.0249 & 0.8012 & -0.8759 & 3.2830 \\
\hline & Capital Input & $\operatorname{lnCAP}$ & 9.4736 & 0.7789 & 7.2693 & 10.9590 \\
\hline & Labor Input & $\operatorname{lnLAB}$ & 7.6568 & 0.7819 & 5.7339 & 8.8198 \\
\hline \multirow[t]{4}{*}{$\begin{array}{c}\text { Control } \\
\text { Variables }\end{array}$} & $\begin{array}{l}\text { Government } \\
\text { Intervention }\end{array}$ & GI & 0.2467 & 0.1016 & 0.1103 & 0.6269 \\
\hline & Urbanization Rate & URB & 0.5711 & 0.1230 & 0.3496 & 0.8960 \\
\hline & $\begin{array}{l}\text { Industrial } \\
\text { Structure }\end{array}$ & IS & 0.4469 & 0.0846 & 0.1860 & 0.5900 \\
\hline & $\begin{array}{c}\text { Physical } \\
\text { Infrastructure }\end{array}$ & $\operatorname{lnINF}$ & 2.6748 & 0.3549 & 1.3962 & 3.2511 \\
\hline
\end{tabular}

\subsection{Preliminary Investigation}

To begin with, a preliminary investigation was performed by looking at the statistics of the selected variables and provinces from 2011 to 2018. Table 3 displays the development and interprovincial differences of China's digital finance index and its three subindices. The aggregated indices implied that the value rose significantly from 40.80 in 2011 to 301.07 in 2018 , an average annual growth rate of $33.05 \%$. The values of all provinces showed a considerable increase as well, which indicated that China's digital finance experienced rapid growth over the past several years. However, obvious differences were seen for both regions and provinces. Among the selected 30 provinces, Shanghai had the highest value of the digital financial index, 80.19 in 2011 and 377.73 in 2018, while Qinghai had the lowest value in both 2011 and 2018. During the sample period, the development of digital finance in the eastern region showed an upward trend, and the increase rate was always higher than that in the central and western regions, while the differences between the central 
and western regions were negligible. The growth rate in the central and western regions accelerated significantly, reflecting the inclusion of digital finance to some extent.

Table 3. The development of digital finance in China.

\begin{tabular}{|c|c|c|c|c|c|c|c|c|}
\hline \multirow[b]{2}{*}{ Regions } & \multicolumn{4}{|c|}{2011} & \multicolumn{4}{|c|}{2018} \\
\hline & $\begin{array}{c}\text { Index } \\
\text { Aggregate }\end{array}$ & $\begin{array}{l}\text { Coverage } \\
\text { Breadth }\end{array}$ & $\begin{array}{l}\text { Usage } \\
\text { Depth }\end{array}$ & $\begin{array}{l}\text { Digitization } \\
\text { Level }\end{array}$ & $\begin{array}{c}\text { Index } \\
\text { Aggregate }\end{array}$ & $\begin{array}{l}\text { Coverage } \\
\text { Breadth }\end{array}$ & $\begin{array}{l}\text { Usage } \\
\text { Depth }\end{array}$ & $\begin{array}{c}\text { Digitization } \\
\text { Level }\end{array}$ \\
\hline Beijing & 79.41 & 97.53 & 72.23 & 32.59 & 368.54 & 353.87 & 366.78 & 420.19 \\
\hline Tianjin & 60.58 & 69.37 & 53.33 & 44.72 & 316.88 & 295.35 & 317.94 & 386.10 \\
\hline Hebei & 32.42 & 18.46 & 44.19 & 57.15 & 282.77 & 264.06 & 267.92 & 371.55 \\
\hline Liaoning & 43.29 & 44.96 & 44.64 & 35.33 & 290.95 & 271.81 & 279.48 & 375.01 \\
\hline Shanghai & 80.19 & 98.85 & 86.24 & 7.58 & 377.73 & 346.33 & 400.40 & 440.26 \\
\hline Jiangsu & 62.08 & 66.70 & 79.22 & 15.71 & 334.02 & 311.95 & 333.09 & 408.62 \\
\hline Zhejiang & 77.39 & 85.53 & 93.52 & 21.22 & 357.45 & 330.17 & 372.01 & 421.07 \\
\hline Fujian & 61.76 & 63.28 & 68.51 & 44.50 & 334.44 & 312.31 & 334.30 & 407.76 \\
\hline Shandong & 38.55 & 33.67 & 47.16 & 39.01 & 301.13 & 281.99 & 287.85 & 388.48 \\
\hline Guangdong & 69.48 & 63.41 & 80.97 & 68.66 & 331.92 & 312.44 & 329.93 & 399.86 \\
\hline Hainan & 45.56 & 30.96 & 57.74 & 71.63 & 309.72 & 294.40 & 300.23 & 377.54 \\
\hline Shanxi & 33.41 & 28.94 & 21.61 & 69.57 & 283.65 & 277.03 & 249.73 & 367.19 \\
\hline Inner Mongolia & 28.89 & 24.65 & 30.27 & 40.35 & 271.57 & 269.49 & 232.31 & 349.76 \\
\hline Jilin & 24.51 & 23.75 & 24.04 & 27.86 & 276.08 & 256.55 & 255.23 & 378.46 \\
\hline Heilongjiang & 33.58 & 21.12 & 36.28 & 69.83 & 274.73 & 256.12 & 254.88 & 372.28 \\
\hline Anhui & 33.07 & 20.20 & 55.58 & 34.66 & 303.83 & 273.41 & 309.62 & 393.79 \\
\hline Jiangxi & 29.74 & 13.97 & 54.82 & 36.21 & 296.23 & 266.46 & 296.52 & 394.00 \\
\hline Henan & 28.40 & 13.54 & 38.11 & 59.81 & 295.76 & 278.46 & 275.74 & 389.27 \\
\hline Hubei & 39.82 & 35.17 & 53.56 & 30.18 & 319.48 & 292.56 & 322.44 & 402.99 \\
\hline Hunan & 32.68 & 15.33 & 60.73 & 39.02 & 286.81 & 258.07 & 286.55 & 382.19 \\
\hline Guangxi & 33.89 & 19.98 & 44.06 & 61.33 & 289.25 & 270.41 & 272.49 & 381.93 \\
\hline Chongqing & 41.89 & 40.38 & 47.46 & 36.77 & 301.53 & 285.11 & 285.60 & 384.74 \\
\hline Sichuan & 40.16 & 29.02 & 58.56 & 43.50 & 294.30 & 266.15 & 295.83 & 384.51 \\
\hline Guizhou & 18.47 & 3.06 & 27.51 & 52.92 & 276.91 & 267.39 & 241.33 & 373.01 \\
\hline Yunnan & 24.91 & 7.47 & 48.39 & 39.81 & 285.79 & 262.29 & 278.84 & 376.06 \\
\hline Shaanxi & 40.96 & 37.81 & 29.74 & 71.74 & 295.95 & 281.05 & 277.15 & 379.31 \\
\hline Gansu & 18.84 & 4.99 & 12.76 & 75.61 & 266.82 & 261.29 & 227.52 & 356.54 \\
\hline Qinghai & 18.33 & 1.96 & 6.76 & 93.42 & 263.12 & 251.69 & 235.31 & 351.43 \\
\hline Ningxia & 31.31 & 32.27 & 23.16 & 42.96 & 272.92 & 274.25 & 225.27 & 355.14 \\
\hline Xinjiang & 20.34 & 12.92 & 23.60 & 38.92 & 271.84 & 267.35 & 232.94 & 357.37 \\
\hline Average & 40.80 & 35.31 & 47.49 & 46.75 & 301.07 & 282.99 & 288.17 & 384.21 \\
\hline
\end{tabular}

Notes: Average means the average value of each index in the selected 30 provinces. Source: Guo et al. [11].

As for the subindices, the coverage breadth, usage depth, and digitization level all showed an upward trend during the study period. The average value of coverage breadth, usage depth, and digitization level surged dramatically throughout 2011-2018, from 34.28 to $281.92,46.93$ to 287.50 , and 46.32 to 383.70 , respectively. The interprovincial differences of coverage breadth and usage depth were basically the same, with the highest development degree in the eastern region and the lowest in the central and western regions. In contrast, the interprovincial differences of digitization level were different, with the central and western regions developing faster, which revealed that the improvement of the digitization level accounted for the convergence of the development of digital finance in recent years. Consequently, the analysis of the development of different dimensions of digital finance is conducive to exploring the influence of digital finance on economic development.

When it comes to the nexus between digital finance and economic growth, Figure 1 reports the national average development level of digital finance and economic growth from 2011 to 2018. It can be seen that the development of digital finance and economic growth is consistent: both show an upward trend. The development of coverage breadth and usage depth exhibits a similar pattern, excluding digitization level. The level of digitization experienced a considerable rise, with a peak of 399.90 seen in 2015, followed 
by a sharp fall over the next two years until it rose again from 2017 on. Furthermore, the full-sample scatter diagram of digital finance and economic growth from the national level is displayed in Figure 2. It can be seen that there was a positive correlation between the two, which indicates that digital finance is conducive to economic growth, laying the foundation for our subsequent empirical analysis.

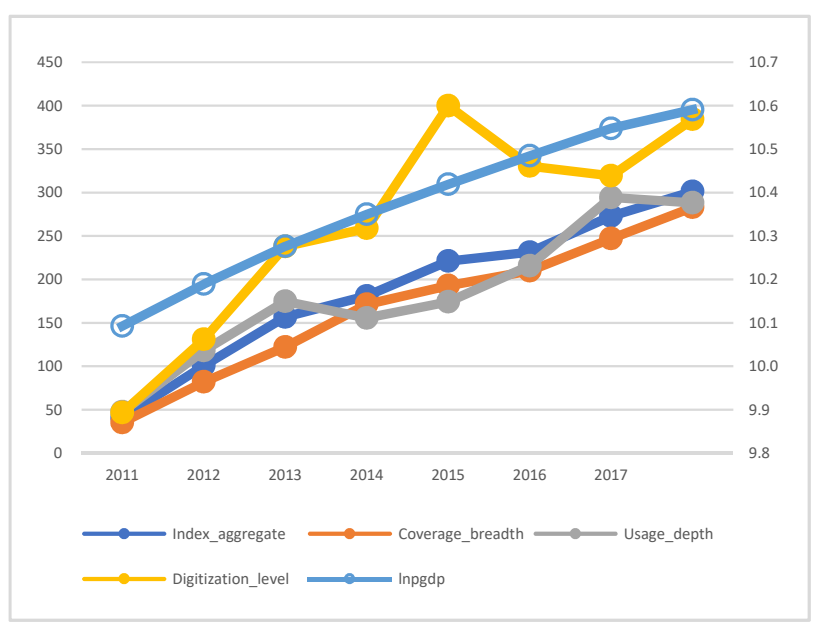

Figure 1. The development of digital finance and growth in GDP per capita.

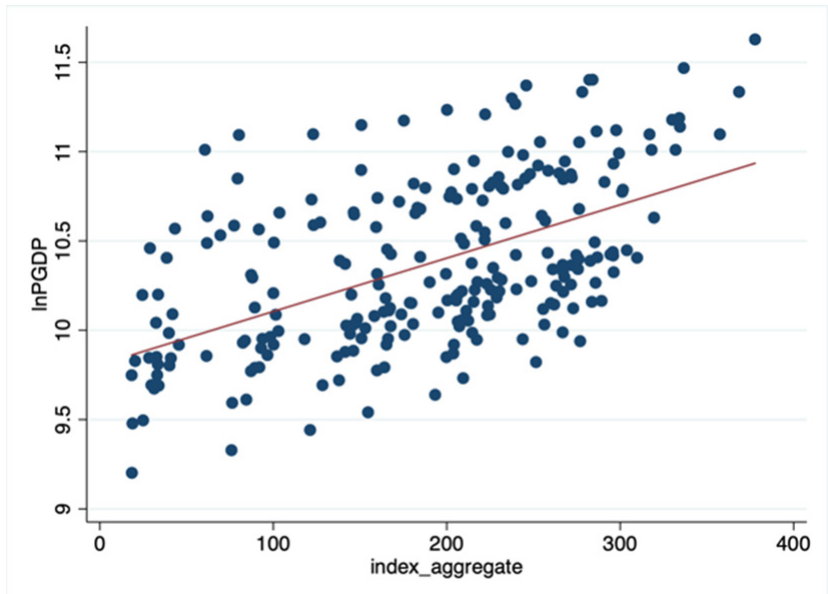

Figure 2. The relationship between digital finance and growth in GDP per capita.

Table 4 presents the results of the correlation coefficient test of each variable. Economic growth (lnPGDP) was positively correlated with digital finance (DF), as expected, and the coefficient was very high (0.5405). Moreover, the correlation coefficients between variables were relatively small and most of them passed the significance test of $5 \%$. As a consequence, the problem of severe multicollinearity amongst the selected variables was deemed nonexistent and dismissed in the subsequent study. Based on the correlation matrix, we argue that economic growth was statistically significantly correlated with all explanatory variables except for labor force $(\ln L A B)$, and then a rigorous empirical investigation was undertaken to further determine the essence of their relationship in the long run. 
Table 4. Correlation matrix.

\begin{tabular}{|c|c|c|c|c|c|c|c|c|}
\hline & $\operatorname{lnPGDP}$ & DF & $\operatorname{lnCAP}$ & $\ln L A B$ & GI & URB & IS & $\operatorname{lnINF}$ \\
\hline $\operatorname{lnPGDP}$ & 1.0000 & & & & & & & \\
\hline DF & $0.5405^{* * *}$ & 1.0000 & & & & & & \\
\hline $\operatorname{lnCAP}$ & $0.2935^{* * *}$ & $0.3411^{* * *}$ & 1.0000 & & & & & \\
\hline $\operatorname{lnLAB}$ & 0.0719 & 0.0720 & $0.8778^{* * *}$ & 1.0000 & & & & \\
\hline GI & $-0.5022 * * *$ & -0.0525 & $-0.6879^{* * *}$ & $-0.6962 * * *$ & 1.0000 & & & \\
\hline URB & $0.9133^{* * *}$ & $0.4171^{* * *}$ & 0.0234 & $-0.1355^{* * *}$ & $-0.3823^{* * *}$ & 1.0000 & & \\
\hline IS & $-0.2659^{* * *}$ & $-0.4769 * * *$ & $0.2577^{* * *}$ & $0.2471^{* * *}$ & $-0.1910^{* * *}$ & $-0.3724^{* * *}$ & 1.0000 & \\
\hline $\operatorname{lnINF}$ & $-0.1247^{* *}$ & 0.0926 & $0.3484^{* * *}$ & $0.1841^{* * *}$ & $-0.1326^{* * *}$ & $-0.3477^{* * *}$ & $0.3186^{* * *}$ & 1.0000 \\
\hline
\end{tabular}

Notes: ${ }^{* *}, * * *$ imply a significance level of 0.05 , and 0.01 , respectively.

\section{Results}

\subsection{Baseline Results}

In light of the examination results of the Hausman Test ( $p=0.000$, which means that the null hypothesis is rejected), fixed effects models were adopted to test the impact of digital finance on economic growth. Table 5 displays the benchmark regression results. The first and second columns show that digital finance had a positive driving effect on GDP per capita at a confidence level of $1 \%$. Additionally, to tackle the cross-section autocorrelation, Driscoll-Kraay standard errors were applied. As shown in column (3), the coefficient was still significantly positive at a magnitude of 0.127 , which implies that digital finance was a significant driver of economic growth.

Table 5. Estimates of the impact of digital finance on GDP per capita from 2011 to 2018.

\begin{tabular}{|c|c|c|c|c|c|c|}
\hline Variables & (1) & (2) & (3) & (4) & (5) & (6) \\
\hline $\mathrm{DF}$ & $\begin{array}{c}0.200^{* * *} \\
(0.004)\end{array}$ & $\begin{array}{c}0.127^{* * *} \\
(0.012)\end{array}$ & $\begin{array}{c}0.127^{* * *} \\
(0.012)\end{array}$ & & & \\
\hline C_D & & & & $\begin{array}{c}0.142^{* * *} \\
(0.014)\end{array}$ & & \\
\hline U_S & & & & & $\begin{array}{c}0.075^{* * *} \\
(0.009)\end{array}$ & \\
\hline D_L & & & & & & $\begin{array}{c}0.032^{* * *} \\
(0.006)\end{array}$ \\
\hline $\operatorname{lnCAP}$ & & $\begin{array}{c}0.096^{* * *} \\
(0.018)\end{array}$ & $\begin{array}{c}0.096^{* * * *} \\
(0.012)\end{array}$ & $\begin{array}{c}0.108^{* * *} \\
(0.018)\end{array}$ & $\begin{array}{c}0.138^{* * *} \\
(0.019)\end{array}$ & $\begin{array}{c}0.109^{* * *} \\
(0.022)\end{array}$ \\
\hline $\ln L A B$ & & $\begin{array}{c}-0.004 \\
(0.092)\end{array}$ & $\begin{array}{c}-0.004 \\
(0.032)\end{array}$ & $\begin{array}{l}-0.021 \\
(0.094)\end{array}$ & $\begin{array}{c}0.131 \\
(0.098)\end{array}$ & $\begin{array}{c}0.241^{* *} \\
(0.104)\end{array}$ \\
\hline GI & & $\begin{array}{l}-0.237 \\
(0.214)\end{array}$ & $\begin{array}{l}-0.237 \\
(0.160)\end{array}$ & $\begin{array}{l}-0.179 \\
(0.216)\end{array}$ & $\begin{array}{c}0.099 \\
(0.230)\end{array}$ & $\begin{array}{l}-0.064 \\
(0.255)\end{array}$ \\
\hline URB & & $\begin{array}{c}1.276^{* * *} \\
(0.270)\end{array}$ & $\begin{array}{c}1.276^{* * * *} \\
(0.242)\end{array}$ & $\begin{array}{c}0.919^{* * *} \\
(0.294)\end{array}$ & $\begin{array}{c}1.764^{* * *} \\
(0.283)\end{array}$ & $\begin{array}{c}2.594^{* * *} \\
(0.278)\end{array}$ \\
\hline IS & & $\begin{array}{c}0.049 \\
(0.139)\end{array}$ & $\begin{array}{c}0.049 \\
(0.260)\end{array}$ & $\begin{array}{c}0.091 \\
(0.144)\end{array}$ & $\begin{array}{c}-0.295^{* *} \\
(0.141)\end{array}$ & $\begin{array}{c}-0.464^{* * * *} \\
(0.150)\end{array}$ \\
\hline $\operatorname{lnINF}$ & & $\begin{array}{c}0.138^{* * *} \\
(0.039)\end{array}$ & $\begin{array}{c}0.138 \\
(0.080)\end{array}$ & $\begin{array}{c}0.133^{* * *} \\
(0.040)\end{array}$ & $\begin{array}{c}0.185^{* * *} \\
(0.043)\end{array}$ & $\begin{array}{c}0.161^{* * *} \\
(0.046)\end{array}$ \\
\hline Constant & $\begin{array}{c}9.992^{* * *} \\
(0.009)\end{array}$ & $\begin{array}{c}8.190 * * * \\
(0.706)\end{array}$ & $\begin{array}{c}8.190^{* * *} \\
(0.448)\end{array}$ & $\begin{array}{c}8.390 * * * \\
(0.728)\end{array}$ & $\begin{array}{c}6.525 * * * \\
(0.722)\end{array}$ & $\begin{array}{c}5.724^{* * *} \\
(0.769)\end{array}$ \\
\hline Observations & 240 & 240 & 240 & 240 & 240 & 240 \\
\hline R-squared & 0.906 & 0.944 & 0.944 & 0.943 & 0.933 & 0.922 \\
\hline
\end{tabular}

With regard to control variables, the coefficients of capital input and urbanization rate were significantly positive at the level of $1 \%$, suggesting that the higher the level of capital investment and urbanization, the higher the degree of economic growth. Specifically, capital input was the main source of funds and an important guarantee of economic growth, while urbanization stimulated population mobility-namely, the inflow of rural labor force 
brought human capital to cities, which contributed to economic growth. Infrastructure also had positive impacts on economic growth, which indicates that the improvement of regional infrastructure may motivate economic growth. We noted that the coefficient of labor input was negative but not significant, which means that an increase in labor input cannot exert a positive effect on economic growth. The promoting effect of labor input on economic growth was prominent in the early stage of reform and opening-up; however, under the new normal of innovation-driven development, labor input no longer played a decisive role, which is congruent with previous research that China's demographic dividend is gradually disappearing [60] and new economic growth drivers should be sought. In terms of government intervention, the regression coefficient was negative but not statistically significant, proving that the role of current government expenditure in stimulating China's economic growth has gradually weakened, which confirms the strategy "let the market play a decisive role in resource allocation" (p. 17) [61]. The coefficient of industry structure was positive but not significant. An increase in the proportion of the secondary industry will lead to industrial agglomeration in a region to better exert agglomeration externalities and economies of scale, so as to foster economic growth. The failure of the significance test implies that the structure of China's secondary industry needs to be improved and transformation and upgrading are required.

Since digital finance is a comprehensive and multidimensional concept, we further examined the impacts of three subindicators on economic growth. The results are shown in columns (4), (5), and (6) of Table 5, which are, respectively, coverage breadth, usage depth, and digitization level. The results show that improvements in coverage breadth, usage depth, and digitization level all have significantly positive impacts on economic growth, with coefficients of $0.142,0.0749$, and 0.0323 , respectively. Among them, coverage breadth has the highest promotion effect, followed by usage depth, and digitization level is the lowest. The coverage breadth of digital finance emphasizes the provision of adequate digital financial services, suggesting that increasing the supply of digital financial services has a positive effect on regional economic growth. This enlightens government authorities as to how to vigorously support and optimize the construction of financial infrastructure in order to expand the coverage of digital financial services. Usage depth measures the actual usage of digital financial services and its connotation is the effective demand for digital financial services. A positive impact indicates that abundant financial tools and products have effectively satisfied the corresponding demand and significantly driven regional economic growth. Effective demand closely pertains to the identification of financial knowledge, which underlines the importance of popularizing financial knowledge to enhance the pertinence and purposiveness of financial services on the demand side for the sake of better economic growth. Digitization level embodies the convenience, low cost, and credit of financial services, which are the main factors affecting users' choices. This requires the local government to actively expedite the informatization of financial infrastructure, focusing on the role of innovative technologies such as big data, cloud computing, and blockchain, so as to improve transaction efficiency and promote economic growth. To conclude, digital finance can promote the diversification of financial products to reduce transaction costs, lower the threshold of financial services, and improve access to financial services to boost the economy.

\subsection{Heterogeneity Results}

To deepen the understanding of the nexus between digital finance and economic growth, this section further investigates the heterogeneity of digital finance to promote economic growth. Table 6 reports the heterogeneity results of the impact of digital finance on economic growth in terms of regions, urbanization level, and physical capital. Due to differences in resource endowments and development stages, both digital finance and economic growth show obvious heterogeneity in the regional distribution, as can be seen in the previous preliminary investigation. Columns (1) and (2) of Table 6 display the regression results of the eastern and midwestern regions in China. According to 
the magnitude of coefficients, in comparison to the eastern region, digital finance has a stronger positive effect on economic growth in the central and western regions, indicating the inclusiveness of the development of digital finance. Then the samples were categorized into two groups, provinces with higher urbanization rate (above the median) and those with lower urbanization rate (below the median), and the estimation results are shown in columns (3) and (4) of Table 6. The coefficients in lower urbanization provinces and higher urbanization provinces are 0.107 and 0.0982 , suggesting that the lower the urbanization level, the greater the marginal utility of digital finance. A possible interpretation for the results is that the development of digital finance can make up for deficiencies in traditional finance, alleviate financial exclusion, and enable low-urbanized areas to enjoy convenient financial services, thus promoting economic growth in low-urbanized areas to a greater extent. Finally, the total fixed assets of the whole society were applied as the proxy variable of physical capital, and the provinces were classified into lower physical capital (below the median) and higher physical capital (above the median). The two sets of samples were then used for regression estimation and the results are shown in the fifth and sixth columns in Table 6. Digital finance promoted the economic growth of both samples, but, interestingly, the promotion effect was greater for regions with lower physical capital. Digital finance is committed to serving agriculture, rural areas, and farmers to promote rural revitalization, focusing on small and micro businesses, urban low-income people, and other vulnerable groups. Generally speaking, regions with higher physical capital have numerous traditional financial outlets and strong accessibility of financial services, and digital finance is merely one of many financial services to choose from. In contrast, for regions with lower physical capital, digital finance is particularly important for economic growth, which further highlights the inclusiveness of digital finance.

Table 6. Heterogeneous impact of digital finance on GDP per capita from 2011 to 2018.

\begin{tabular}{|c|c|c|c|c|c|c|}
\hline Variables & (1) & (2) & (3) & (4) & (5) & (6) \\
\hline DF & $\begin{array}{c}0.081^{* * *} \\
(0.023)\end{array}$ & $\begin{array}{c}0.107^{* * *} \\
(0.018)\end{array}$ & $\begin{array}{c}0.107^{* * * *} \\
(0.018)\end{array}$ & $\begin{array}{c}0.098^{* * *} \\
(0.020)\end{array}$ & $\begin{array}{c}0.068^{* * *} \\
(0.020)\end{array}$ & $\begin{array}{c}0.126^{* * *} \\
(0.018)\end{array}$ \\
\hline $\operatorname{lnCAP}$ & $\begin{array}{c}0.144^{* * *} \\
(0.033)\end{array}$ & $\begin{array}{c}0.078^{* * *} \\
(0.021)\end{array}$ & $\begin{array}{c}0.116^{* * *} \\
(0.027)\end{array}$ & $\begin{array}{c}0.091^{* * *} \\
(0.024)\end{array}$ & $\begin{array}{c}0.309^{* * *} \\
(0.050)\end{array}$ & $\begin{array}{c}0.081^{* * *} \\
(0.023)\end{array}$ \\
\hline $\ln L A B$ & $\begin{array}{c}0.100 \\
(0.166)\end{array}$ & $\begin{array}{c}0.100 \\
(0.111)\end{array}$ & $\begin{array}{c}0.033 \\
(0.138)\end{array}$ & $\begin{array}{c}0.195 \\
(0.132)\end{array}$ & $\begin{array}{c}0.234 \\
(0.150)\end{array}$ & $\begin{array}{c}0.010 \\
(0.154)\end{array}$ \\
\hline GI & $\begin{array}{c}0.490 \\
(0.445)\end{array}$ & $\begin{array}{c}-0.424 \text { * } \\
(0.221)\end{array}$ & $\begin{array}{c}0.125 \\
(0.351)\end{array}$ & $\begin{array}{c}-0.533^{* *} \\
(0.260)\end{array}$ & $\begin{array}{c}-1.708^{* * *} \\
(0.298)\end{array}$ & $\begin{array}{c}0.122 \\
(0.291)\end{array}$ \\
\hline URB & $\begin{array}{c}0.494 \\
(0.424)\end{array}$ & $\begin{array}{c}2.604^{* * *} \\
(0.368)\end{array}$ & $\begin{array}{c}1.215^{* * * *} \\
(0.411)\end{array}$ & $\begin{array}{c}2.535^{* * *} \\
(0.435)\end{array}$ & $\begin{array}{c}0.849 \text { ** } \\
(0.384)\end{array}$ & $\begin{array}{c}1.156^{* * *} \\
(0.384)\end{array}$ \\
\hline IS & $\begin{array}{c}-0.776 \text { * } \\
(0.392)\end{array}$ & $\begin{array}{c}0.095 \\
(0.133)\end{array}$ & $\begin{array}{c}-0.204 \\
(0.224)\end{array}$ & $\begin{array}{l}0.291 \text { * } \\
(0.165)\end{array}$ & $\begin{array}{c}-0.375 \text { * } \\
(0.207)\end{array}$ & $\begin{array}{c}0.173 \\
(0.204)\end{array}$ \\
\hline $\operatorname{lnINF}$ & $\begin{array}{c}0.341^{* * *} \\
(0.072)\end{array}$ & $\begin{array}{l}-0.036 \\
(0.052)\end{array}$ & $\begin{array}{c}0.222 * * * \\
(0.059)\end{array}$ & $\begin{array}{l}-0.002 \\
(0.057)\end{array}$ & $\begin{array}{c}0.037 \\
(0.051)\end{array}$ & $\begin{array}{c}0.172 * * * \\
(0.058)\end{array}$ \\
\hline Constant & $\begin{array}{c}7.464^{* * *} \\
(1.350)\end{array}$ & $\begin{array}{c}7.292^{* * *} \\
(0.828)\end{array}$ & $\begin{array}{c}7.793 * * * \\
(1.087)\end{array}$ & $\begin{array}{c}6.296^{* * *} \\
(1.037)\end{array}$ & $\begin{array}{c}5.126^{* * *} \\
(1.270)\end{array}$ & $\begin{array}{c}8.130 * * * \\
(1.008)\end{array}$ \\
\hline Observations & 88 & 152 & 120 & 120 & 120 & 120 \\
\hline R-squared & 0.930 & 0.965 & 0.930 & 0.965 & 0.980 & 0.913 \\
\hline
\end{tabular}

\subsection{Mechanism Results}

In this part, we discuss the transmission mechanism of digital finance and how it affects economic growth. In the context of the new normal of China's economy, entrepreneurship is crucial to achieving sustainable development, and finance is the most important prerequisite for technological innovation and regional entrepreneurship. In addition, the development of digital finance driven by Internet technology has made financial services more efficient and sharply reduced the financial constraints of innovative entrepreneurs, especially those excluded from traditional finance. Therefore, a classical mediating effect model was adopted to empirically examine whether digital finance indirectly affects 
economic growth through entrepreneurship. Table 7 reports the mechanism results of digital finance on economic growth when entrepreneurship was selected as the mediating variable. The results in column (2) show that the coefficient of the impact of digital finance on entrepreneurship was 0.097 at the level of $1 \%$, indicating that digital finance positively promoted entrepreneurship. After further controlling the variable of entrepreneurship in the third column, the coefficient of entrepreneurship and digital finance both passed the significance test. Meanwhile, the value of the coefficient of digital finance obviously decreased from 0.127 in column (1) to 0.118 , suggesting that a mediating effect of entrepreneurship exists. In addition, the Sobel test was used to identify the significance of the mediating effect. The results show that the coefficient is 0.021 and the $p$-value was less than 0.01 , implying that the mediating effect of entrepreneurship was significant, accounting for $45.623 \%$ of the total effect. To maintain the robustness of the mediating effect results, in light of the previous studies [47], this part further adopted the proportion of self-employed or business owners in the labor force, i.e., the self-employment ratio (SER), as the proxy variable of entrepreneurship to conduct the robustness analysis. The results are shown in the fourth and fifth columns of Table 7 and are basically in line with the above conclusion, which indicates that entrepreneurship plays a mediating effect between digital finance and economic growth.

Table 7. Mechanism test of digital finance and entrepreneurship.

\begin{tabular}{|c|c|c|c|c|c|}
\hline \multirow{2}{*}{ Variables } & (1) & (2) & (3) & (4) & (5) \\
\hline & lnPGDP & ENTREP & $\ln P G D P$ & SER & $\ln P G D P$ \\
\hline DF & $\begin{array}{c}0.127 * * * \\
(0.012)\end{array}$ & $\begin{array}{c}0.097 * * * \\
(0.031)\end{array}$ & $\begin{array}{c}0.118^{* * *} \\
(0.012)\end{array}$ & $\begin{array}{c}0.116^{* * *} \\
(0.015)\end{array}$ & $\begin{array}{c}0.102^{* * *} \\
(0.013)\end{array}$ \\
\hline ENTREP & & & $\begin{array}{c}0.088^{* * *} \\
(0.026)\end{array}$ & & \\
\hline SER & & & & & $\begin{array}{c}0.212 \text { *** } \\
(0.052)\end{array}$ \\
\hline $\operatorname{lnCAP}$ & $\begin{array}{c}0.096^{* * *} \\
(0.018)\end{array}$ & $\begin{array}{c}0.106 * * \\
(0.047)\end{array}$ & $\begin{array}{c}0.086^{* * *} \\
(0.017)\end{array}$ & $\begin{array}{c}0.022 \\
(0.023)\end{array}$ & $\begin{array}{c}0.091^{* * *} \\
(0.017)\end{array}$ \\
\hline $\ln L A B$ & $\begin{array}{l}-0.004 \\
(0.092)\end{array}$ & $\begin{array}{c}-1.059 * * * \\
(0.246)\end{array}$ & $\begin{array}{c}0.090 \\
(0.094)\end{array}$ & $\begin{array}{l}-0.033 \\
(0.120)\end{array}$ & $\begin{array}{c}0.004 \\
(0.089)\end{array}$ \\
\hline GI & $\begin{array}{l}-0.237 \\
(0.214)\end{array}$ & $\begin{array}{c}0.004 \\
(0.571)\end{array}$ & $\begin{array}{l}-0.237 \\
(0.209)\end{array}$ & $\begin{array}{c}0.064 \\
(0.278)\end{array}$ & $\begin{array}{l}-0.250 \\
(0.207)\end{array}$ \\
\hline URB & $\begin{array}{c}1.276^{* * *} \\
(0.270)\end{array}$ & $\begin{array}{c}-1.352 * \\
(0.719)\end{array}$ & $\begin{array}{c}1.396^{* * *} \\
(0.265)\end{array}$ & $\begin{array}{c}-0.962^{* * * *} \\
(0.350)\end{array}$ & $\begin{array}{c}1.480^{* * * *} \\
(0.265)\end{array}$ \\
\hline IS & $\begin{array}{c}0.049 \\
(0.139)\end{array}$ & $\begin{array}{c}1.274^{* * *} \\
(0.371)\end{array}$ & $\begin{array}{l}-0.063 \\
(0.139)\end{array}$ & $\begin{array}{c}0.358^{* *} \\
(0.180)\end{array}$ & $\begin{array}{l}-0.027 \\
(0.135)\end{array}$ \\
\hline $\operatorname{lnINF}$ & $\begin{array}{c}0.138^{* * *} \\
(0.039)\end{array}$ & $\begin{array}{l}-0.118 \\
(0.104)\end{array}$ & $\begin{array}{c}0.148^{* * *} \\
(0.038)\end{array}$ & $\begin{array}{c}0.083 \\
(0.051)\end{array}$ & $\begin{array}{c}0.120^{* * * *} \\
(0.038)\end{array}$ \\
\hline Constant & $\begin{array}{c}8.190 * * * \\
(0.706)\end{array}$ & $\begin{array}{c}7.468^{* * *} \\
(1.881)\end{array}$ & $\begin{array}{c}7.532 * * * \\
(0.714)\end{array}$ & $\begin{array}{c}0.315 \\
(0.915)\end{array}$ & $\begin{array}{c}8.123^{* * * *} \\
(0.680)\end{array}$ \\
\hline Observations & 240 & 240 & 240 & 240 & 240 \\
\hline R-squared & 0.944 & 0.170 & 0.947 & 0.643 & 0.948 \\
\hline
\end{tabular}

Notes: ${ }^{*},{ }^{* *},{ }^{* * *}$ imply a significance level of $0.01,0.05$, and 0.01, respectively.

\subsection{Robustness Checks}

Digital finance shares some of the characteristics of traditional finance, which has a serious reverse causality relationship with economic growth. To alleviate the potential endogeneity, this part uses historical postal and telecommunications data from each province in 1984 as the instrumental variables of digital finance. On the one hand, the Internet is the continuation of traditional communication technology, and through history, the local telecommunications infrastructure has affected the application of Internet technology in the subsequent stages from factors such as technical level and usage habits, and therefore, related to the development of local digital finance. On the other hand, traditional postal and telecommunications tools, such as landline telephones and post offices, hardly affect 
current economic development due to a decrease in the frequency of utilization. It should be noted that the original data of the selected instrument variables are in cross-sectional form and cannot be used directly for a quantitative analysis of panel data. Referring to the research of Nunn and Qian [62], a time-varying variable was introduced to create panel instrumental variables. Specifically, the number of Internet users nationwide in the previous year and the number of landline telephones (IV1) or per capita post and telecommunications services (IV2) in each province in 1984 were used to construct interaction terms as an instrumental variable for the province's digital finance in a year.

The results in columns (1) and (2) of Table 8 show that, after considering endogeneity, the positive impact of digital finance on economic growth is consistent, and the results are both significant at the level of $1 \%$. Moreover, the $p$-values of the Anderson cannon. corr. LM statistic of the under-identification test were both 0.000 , leading us to reject the null hypothesis. In the weak identification test, the Cragg-Donald Wald F statistic was greater than the Stock-Yogo critical values at the level of $10 \%$, indicating that there was no problem of weak correlation in either of the two instrumental variables. Last but not least, the results of endogeneity tests showed that endogeneity existed for digital finance, indicating that the use of instrumental variables is necessary. In general, the above test shows the rationality of the selected instrumental variables.

Table 8. Robustness checks.

\begin{tabular}{|c|c|c|c|c|c|}
\hline & (1) & (2) & (3) & (5) & (4) \\
\hline & IV1 & IV2 & $\operatorname{lnGDP}$ & $\begin{array}{c}\text { Excluding } \\
\text { Municipalities }\end{array}$ & Winsorization \\
\hline DF & $\begin{array}{c}0.196^{* * *} \\
(0.023)\end{array}$ & $\begin{array}{c}0.162 * * * \\
(0.019)\end{array}$ & $\begin{array}{l}0.184^{* * *} \\
(0.011)\end{array}$ & $\begin{array}{l}0.122 * * * \\
(0.012)\end{array}$ & $\begin{array}{l}0.126^{* * *} \\
(0.012)\end{array}$ \\
\hline $\begin{array}{l}\text { Anderson } \\
\text { canon. corr. } \\
\text { LM statistic }\end{array}$ & $59.119 * * *$ & $82.921 * * *$ & & & \\
\hline $\begin{array}{l}\text { Cragg-Donald } \\
\text { Wald F statistic }\end{array}$ & 79.540 & 132.462 & & & \\
\hline & $\{16.38\}$ & $\{16.38\}$ & & & \\
\hline $\begin{array}{c}\text { Endogeneity } \\
\text { test }\end{array}$ & $14.682 * * *$ & $6.148^{* *}$ & & & \\
\hline $\begin{array}{c}\text { Control } \\
\text { variables }\end{array}$ & YES & YES & YES & YES & YES \\
\hline Observations & 240 & 240 & 240 & 208 & 240 \\
\hline R-squared & 0.934 & 0.942 & 0.955 & 0.960 & 0.943 \\
\hline
\end{tabular}

Moreover, we performed robustness checks from the following three aspects. First, the logarithm of real GDP was adopted as an alternative indicator to measure economic growth. Second, we found that municipalities (i.e., Beijing, Tianjin, Shanghai, and Chongqing) tend to have location advantages and economic advantages, and thus preferential policies under the direct jurisdiction of the central government, which may lead to inconsistent digital financial development, thus leading to deviations from the research conclusion. Therefore, the data of the four municipalities were removed in this part. Third, the main explanatory variables were winsorized at a level of $1 \%$ to prevent the influence of outliers on the consequences of the research. Panel fixed effects models were used to estimate all the above tests and the results are shown in columns (3), (4), and (5) of Table 8. The results of all three robustness tests suggest that digital finance significantly promotes economic growth, in line with the aforementioned consequence, which confirmed that the main conclusion is relatively robust.

\section{Conclusions and Policy Implications}

President Xi Jinping pointed out that when financial systems are vibrant and stable, so is the economy. As a representative of the new financial development models, digital finance is of great significance for China to achieve high-quality development through 
the construction of a digital economy. On account of the fact that digital finance has greatly affected China's economic performance, from the perspective of entrepreneurship and using the yearly data of 30 provinces in China, we first carried out a preliminary investigation, and then adopted the panel econometric model and mediating effect model to conduct multidimensional empirical analyses to explore the influencing mechanism of digital finance on economic growth. The main conclusions are as follows: First, digital finance has a positive and significant impact on economic growth and has become an important driving force for high-quality development in China in the digital era. Through the introduction of instrumental variables and other robustness tests, this conclusion was validated. Three subindicators: coverage breadth, usage depth, and digitalization level, all had a significantly positive effect on economic performance. Second, drawing on the heterogeneity analysis, the central and western regions, areas with lower urbanization level and lower physical capital, played a greater marginal role in digital finance and enjoyed a higher dividend of digital finance compared to their counterparts-that is, digital finance had a greater promoting effect on the economic development of underdeveloped regions, verifying the inclusiveness of digital finance. Third, entrepreneurship was a mechanism of digital finance, enabling economic growth. The two-wheel driving phenomenon formed by the "Internet + " and "the nationwide initiative spurring entrepreneurship and innovation" is of great significance for bolstering China's economy. In light of these results, relevant policy implications and practical inferences are presented below.

Firstly, based on the reality that digital finance has become a new driving force for economic growth, advanced technologies such as big data, cloud computing, blockchain, artificial intelligence, etc., should be further applied to aid the continuous development of digital finance. Specifically, the government should take steps to expand the coverage breadth and usage depth and to tap the functions of digital finance to advance the construction of a digital China and further consolidate the dividends brought about by digital finance, with information technology as its carrier. Secondly, the positive effect of digital finance on underdeveloped areas still needs to be strengthened, indicating that dynamic and differentiated digital financial measures should be implemented to make digital finance become the "hardware" technical support to effectively mitigate the imbalance of regional development and achieve inclusiveness. Policymakers should expand accessibility and maintain the stability of digital finances to help vulnerable and economically marginalized segments of the country address difficulties in financing. For instance, in the central and western regions, where the coverage of traditional financial outlets is relatively low, Internet technology could be used to expand the financing channels to reduce the transaction costs and facilitate financing. Finally, digital finance brings an endogenous impetus to regional economic development by inspiring entrepreneurship, testifying that Internet technology and financial services can converge to create a new momentum for economic development through entrepreneurship, which is indispensable for economic growth in the new era. Therefore, it is necessary to strengthen the incentive role of innovation and entrepreneurship, and accelerate the protection and liberation of outstanding entrepreneurship, to ensure the optimal allocation of limited credit resources.

Author Contributions: Conceptualization, X.J. and X.W.; methodology, X.J. and J.R.; software, X.J.; validation, X.W., J.R., and Z.X.; formal analysis, X.J.; investigation, J.R.; resources, J.R.; data curation, J.R.; writing-original draft preparation, X.J.; writing-review and editing, J.R. and Z.X.; supervision, X.W.; project administration, Z.X.; funding acquisition, X.W. All authors have read and agreed to the published version of the manuscript.

Funding: This research was funded by the National Social Science Foundation of China, grant number 19BGL047, and the Ministry of Education Humanities and Social Sciences Research Youth Fund Project, grant number 20YJC630167.

Data Availability Statement: The digital inclusive finance index used in this paper can be found at https:/ /idf.pku.edu.cn/yjcg/zsbg/485016.htm. The data presented in this study are available on request from the corresponding author. 
Conflicts of Interest: The authors declare no conflict of interest.

\section{References}

1. Trotsuk, I. Discursive Representations of the (Capitalist) Results of the "Chinese Economic Miracle". Sociol. Obozr. 2020, 19, 310-347.

2. Pontines, V.; Luvsannyam, D.; Batmunkh, K.; Otgonbat, T. The dynamics of business cycle connectedness and the decoupling of Asia-Pacific. Int. J. Financ. Econ. 2021, 1-26. [CrossRef]

3. Nishimura, Y. New normal and new economy: A new growth engine for China. Int. J. Econ. Policy Stud. 2020, 14, 301-312. [CrossRef]

4. Thai-Ha, L.; Anh Tu, C.; Taghizadeh-Hesary, F. Financial inclusion and its impact on financial efficiency and sustainability: Empirical evidence from Asia. Borsa Istanb. Rev. 2019, 19, 310-322.

5. Gomber, P.; Koch, J.A.; Siering, M. Digital Finance and FinTech: Current research and future research directions. J. Bus. Econ. 2017, 87, 537-580. [CrossRef]

6. Visconti, R.M.; Morea, D. Big Data for the Sustainability of Healthcare Project Financing. Sustainability 2019, 11, 17. [CrossRef]

7. Visconti, R.M.; Morea, D. Healthcare Digitalization and Pay-For-Performance Incentives in Smart Hospital Project Financing. Int. J. Environ. Res. Public Health 2020, 17, 2318. [CrossRef]

8. Beck, T.; Pamuk, H.; Ramrattan, R.; Uras, B.R. Payment instruments, finance and development. J. Dev. Econ. 2018, 133, 162-186. [CrossRef]

9. Arner, D.W.; Barberis, J.; Buckley, R.P. RegTech: Building a Better Financial System-ScienceDirect. Handb. Blockchain Digit. Financ. Incl. 2018, 1, 359-373.

10. Victor, A.O.; Group, S. Repositioning Digital Payments to achieve the Financial Inclusion Goals of Financial System Strategy. Available online: https:/ / www.researchgate.net/publication/332268496 (accessed on 8 April 2019).

11. Guo, F.; Wang, J.; Wang, F.; Kong, T.; Zhang, X.; Cheng, Z. Measurig China's Digital Financial Inclusion: Index Compilation and Spatial Characteristics. Q. J. Econ. 2020, 19, 1401-1418.

12. Aghion, P.; Howitt, P. A model of growth through creative destruction. Econometrica 1992, 60, 323-351. [CrossRef]

13. Aghion, P.; Festre, A. Schumpeterian growth theory, Schumpeter, and growth policy design. J. Evol. Econ. 2017, 1, 25-42. [CrossRef]

14. Rajan, R.; Zingales, L. Financial Dependence and Growth. Soc. Ence. Electron. Publ. 1998, 88, 559-586.

15. Levine, R. Finance and Growth: Theory and Evidence. Handb. Econ. Growth 2005, 1, 865-934.

16. Finance, A.O. The role of household debt and delinquency decisions in consumption-based asset pricing. Ann. Financ. 2019, 15, 179-203.

17. Herrenbrueck, L. Frictional asset markets and the liquidity channel of monetary policy. J. Econ. Theory 2019, 181, 82-120. [CrossRef]

18. Bianchiy, M. Credit constraints, entrepreneurial talent, and economic development. HAL 2010, 34, 93. [CrossRef]

19. Festre, A.; Nasica, E. Schumpeter on money, banking and finance: An institutionalist perspective. Eur. J. Hist. Econ. Thought 2009, 16, 325-356. [CrossRef]

20. King, R.G.; Levine, R. Finance, entrepreneurship and growth. J. Monet. Econ. 1993, 32, 513-542. [CrossRef]

21. Lardy, N.R. Financial Repression in China. Policy Briefs 2008. [CrossRef]

22. Huang, Y.; Xun, W. Does Financial Repression Inhibit or Facilitate Economic Growth? A Case Study of Chinese Reform Experience. Oxf. Bull. Econ. Stat. 2011, 73, 833-855. [CrossRef]

23. Hosseinidoust, S.E.; Saatian, A. The effect of financial repression policy on bank liquidity risk (evidence from Central Bank of Iran). Afro-Asian J. Financ. Account. 2020. Available online: https://222.researchgate.net/publication/342750832 (accessed on 1 July 2020).

24. Plantin, G. Bubbles against Financial Repression. Cepr Discuss. Pap. 2020. Available online: https://cepr.org/active/publications/ discussion_papers/dp.php?dpno=15197 (accessed on 1 August 2020).

25. Liu, Z.; Spiegel, M.M.; Zhang, J.; King, R.G.; Plosser, C.I. Optimal capital account liberalization in China. J. Monet. Econ. 2021, 117, 1041-1061. [CrossRef]

26. Guangdong, X.U. China's Financial Repression: Symptoms, Consequences and Causes. Cph. J. Asian Stud. 2018, 36, 28.

27. Kapron, Z. From digital payments to digital finance: How China's tech companies are redefining banking in Asia and soon Europe. J. Paym. Strategy Syst. 2018, 12, 68-73.

28. Arjunwadkar, P.Y. FinTech: The Technology Driving Disruption in the Financial Services Industr; Auerbach Publications: Boca Raton, FL, USA, 2018.

29. Yu, L.; Zhao, D.; Xue, Z.; Gao, Y. Research on the use of digital finance and the adoption of green control techniques by family farms in China. Technol. Soc. 2020, 62, 101323. [CrossRef]

30. Cornelius, K.; Kwon, Y. Digital Finance Revolution in E. Africa: Retail Bank's Adaption to a changing Marketplace. In Proceedings of the 22nd ITS Biennial Conference, Seoul, Korea, 24-27 June 2018.

31. Rana, N.P.; Luthra, S.; Rao, H.R. Key Challenges to Digital Financial Services in Emerging Economies and Developing Countries: The Indian Context. Inf. Technol. People 2019, 33, 198-229. [CrossRef] 
32. Pierrakis, Y.; Collins, L. Crowdfunding: A New Innovative Model of Providing Funding to Projects and Businesses. SSRN Electron. J. 2013. [CrossRef]

33. Nugraheni, N. Crowdfunding-Based Fiduciary Warrant in Providing Capital Loans for Small and Medium Enterprises. Hasanuddin Law Rev. 2020, 6, 224-231. [CrossRef]

34. Lorente, J.C.; Schmukler, S.L. The Fintech Revolution: A threat to global banking? Res. Policy Briefs 2018. Available online: https://ssrn.com/abstract=3255725 (accessed on 14 April 2018).

35. Mohamed, H. Digital Sukuk Issuance for Business Financing. In Beyond Fintech Technology Applications for the Islamic Economy; World Scientific Publishing Co. Pte. Ltd.: Singapore, 2020; pp. 43-67.

36. Keliuotyt-Staniulnien, G.; Kukarnait, M. Financial Innovation Management: Loan Price in the Crowdfunding and Peer-To-Peer Lending Platforms. Mark. Manag. Innov. 2020, 2, 256-274.

37. Grossman, J.; Tarazi, M. Serving Smallholder Farmers: Recent Developments in Digital Finance. 2014. Available online: http:/ / documents.worldbank.org/curated/en/119581468148758424/ (accessed on 1 June 2014).

38. Li, J.; Wu, Y.; Xiao, J.J. The impact of digital finance on household consumption: Evidence from China. Econ. Model. 2020, 86, 317-326. [CrossRef]

39. Kromidha, E.; Yadav, N.; Ilavarasan, P.V. Digital Microfinance Crowdfunding for Disconnected Women Entrepreneurs in India. Int. J. Entrep. Small Bus. 2021, 1, 2-34.

40. Kusimba, S. It is easy for women to ask: Gender and digital finance in Kenya. Econ. Anthropol. 2018, 5, 247-260. [CrossRef]

41. Ozili, P.K. Impact of Digital Finance on Financial Inclusion and Stability. Borsa Istanb. Rev. 2018, 18, 329-340. [CrossRef]

42. Ozili, P.K. Contesting Digital Finance for the Poor. Digit. Policy Regul. Gov. 2020, 22, 135-151.

43. Acs, Z.J.; Szerb, L. Entrepreneurship, Economic Growth and Public Policy. Small Bus. Econ. 2007, 28, 109-122. [CrossRef]

44. Quan, H.V.; La, P.; Vuong, T.T.; Hoang, P.H.; Nguyen, T. Multi-faceted insights of entrepreneurship facing a fast-growing economy: A literature review. Open Econ. 2020, 3, 25-41.

45. Huang, B. A Study on the Effect of Digital Inclusive Finance on the Financial Restraint of Small and Medium-sized Enterprises. E3s Web Conf. 2021, 235, 03014.

46. Zy, A.; Xue, G.A.; Pg, A.; Tao, W.B. What Drives Entrepreneurship in Digital Economy? Evidence from China. Econ. Model. 2019, $82,66-73$.

47. Li, H.; Yang, Z.; Yao, X.; Zhang, H.; Zhang, J. Entrepreneurship, private economy and growth: Evidence from China. China Econ. Rev. 2012, 23, 948-961. [CrossRef]

48. Salas-Fumás, V.; Sanchez-Asin, J.J.; Storey, D. Occupational choice, number of entrepreneurs and output: Theory and empirical evidence with Spanish data. SERIEs 2014, 5, 1-24. [CrossRef]

49. Kadarusman, Y.B. The Impact of Entrepreneurship on Economic Performance in Indonesia. Econ. Financ. Indones. 2020, 66, 1-10. [CrossRef]

50. Civera, J.N.; Bó, M.; López-Muoz, J. Do contextual factors influence entrepreneurship? Spain's regional evidences. Int. Entrep. Manag. J. 2021, 17, 105-129. [CrossRef]

51. Schumpeter, J.; Backhaus, U. The Theory of Economic Development. In European Heritage in Economics and the Social Sciences; Springer: Boston, MA, USA, 2003.

52. Tiba, S.; Rijnsoever, F.; Hekkert, M.P. The lighthouse effect: How successful entrepreneurs influence the sustainability-orientation of entrepreneurial ecosystems. J. Clean. Prod. 2020, 264, 121616. [CrossRef]

53. Szerb, L.; Acs, Z.J.; Ortegaargilés, R.; Komlosi, E. The Regional Entrepreneurship and Development Index-Measuring regional entrepreneurship. Soc. Sci. Electron. Publ. 2013, 54, 420-425.

54. Acs, Z.J.; Stam, E.; Audretsch, D.B.; O'Connor, A. The lineages of the entrepreneurial ecosystem approach. Small Bus. Econ. 2017, 49,1-10. [CrossRef]

55. Stuetzer, M.; Audretsch, D.B.; Obschonka, M.; Gosling, S.D.; Rentfrow, P.J.; Potter, J. Entrepreneurship culture, knowledge spillovers and the growth of regions. Reg. Stud. 2018, 52, 608-618. [CrossRef]

56. Caragliu, A.; Del Bo, C.F.; Kourtit, K.; Nijkamp, P. The winner takes it all: Forward-looking cities and urban innovation. Ann. Reg. Sci. 2016, 56, 617-645. [CrossRef]

57. Alfaro, L.; Chanda, A.; Kalemli-Ozcan, S.; Sayek, S. FDI and economic growth: The role of local financial markets. J. Int. Econ. 2004, 64, 89-112. [CrossRef]

58. Ordeana, X.; Vera-Gilces, P.; Zambrano-Vera, J.; Amaya, A. Does all entrepreneurship matter? The contribution of entrepreneurial activity to economic growth. Acad. Rev. Latinoam. Adm. 2019, 33, 25-48. [CrossRef]

59. Kahn, M.E.; Sun, W.; Wu, J.; Zheng, S. Do Political Connections Help or Hinder Urban Economic Growth? Evidence from 1400 Industrial Parks in China-ScienceDirect. J. Urban. Econ. 2020, 121, 103289. [CrossRef]

60. Taketoshi, K. How and to what extent has the demographic dividend affected China's economic growth? Int. J. Econ. Policy Stud. 2020, 14, 337-350. [CrossRef]

61. Zhang, X.; Yu, L. Distortions, Growth Catch-up, and Sustainable Growth. China Econ. 2018, 13, 14-36. [CrossRef]

62. Nunn, N.; Qian, N. US Food Aid and Civil Conflict. Am. Econ. Rev. 2014, 104, 1630-1666. [CrossRef] 